\title{
Assessment of the Ameliorative Roles of Vitamins A, C and Eon Alanine Aminotransferase (ALT) Productionin Clariasgariepinus (Burchell, 1822) Fingerlings Exposed To Cadmium Chloride
}

\author{
Samuel, Patrick Ozovehe ${ }^{1}$, Arimoro, F. O., ${ }^{1}$ Ayanwale, A. V. ${ }^{1}$ and Mohammad, H. L. ${ }^{2}$
}

Fisheries and Hydrobiology Unit, Department of Animal Biology, Federal University of Technology, Nigeria ${ }^{2}$ Biochemistry Department, Federal University of Technology, Minna, Niger State

\author{
*Corresponding Author: Samuel, Patrick Ozovehe, Fisheries and Hydrobiology Unit, Department of \\ Animal Biology, Federal University of Technology, Minna, Niger State
}

\begin{abstract}
The anthropogenic activities culminating in environmental pollution all over the world thatusually leads to release of plethora of pollutants such as cadmium calls for concern. In the present study the effects of cadmium chloride on the production of antioxidants such as Alanine AminoTransferase (ALT) in C.gariepinus and how such effects can be ameliorated through administration of vitamins were investigated.C.gariepinus fingerlings (whose initial weight ranged from 3-11 $)$ were exposed to sub-lethal concentrations of $C d(00,12 \mathrm{mg} / \mathrm{L}, 16 \mathrm{mg} / \mathrm{L}, 20 \mathrm{mg} / \mathrm{L}$ and $24 \mathrm{mg} / \mathrm{L})$ with replicate in each case. Minimum concentration of the toxicant was taken as the concentration for each of the vitamins and administered across all treatments. Fresh concentrations of both toxicant and vitamins were administered every 72 hours for a period of 12 weeks every time the water medium was changed.The various treatments group include Cd $(C d$ only with T1-T4 and replicates), CdVA (Cd+vitamin A with T1-T4 and replicates), CdVC (Cd+vitamin C with T1-T4 and replicates) and CdVE (Cd+vitamin E with T1-T4 and replicates). 3 samples of the fish were randomly selected and sacrificed from each aquarium tank every 2 weeks of the exposure period. The gills, kidneys and liver were excised from these specimens and homogenized in sodium phosphate buffer. From the results: In samples exposed to Cd only, the ALT production levels in the liver of the fish showed that $T 1$ and $T 4$ in the $2^{\text {nd }}$ and $4^{\text {th }}$ weeks of exposure, respectively are significantly higher than other treatments including the control. The control mean values in the $6^{\text {th }}$ and $8^{\text {th }}$ weeks of exposure, respectively are significantly higher than other treatments. $T 1$ in the $10^{\text {th }}$ week of exposure are significantly higher than other treatments. The highest ALT produced in the liver was65.43 $\pm 0.10 \mathrm{nM} / \mathrm{mg}$ obtained in T4 at the end of the $6^{\text {th }}$ week of exposure. T1 and T4 in the kidneys of the samples at the end of the $2^{\text {nd }}$ and $4^{\text {th }}$ weeks of exposure, respectively are significantly higher than other treatments. The control mean values in the $6^{\text {th }}$ and $10^{\text {th }}$ weeks of exposure are significantly higher than other treatments. T4 inthe $8^{\text {th }}$ week of exposure are significantly higher than other treatments including the control. $T 4$ in the $4^{\text {th }}$ week of exposure recorded the highest ALT value of $71.87 \pm 0.20 \mathrm{nM} / \mathrm{mgin}$ the kidney of the samples. The T3 and T4 in the gills of the samples in the $2^{\text {nd }}$ and $4^{\text {th }}$ weeks of exposure are significantly higher than other treatments. T2 in the $6^{\text {th }}$ week of exposure are significantly higher than other treatments. The control in the $8^{\text {th }}$ and $10^{\text {th }}$ weeks of exposure, respectively are significantly higher than other treatments. The highest ALT produced in the gill was $62.97 \pm 0.05 n M / m g o b t a i n e d ~ i n ~ T 2$ at the end of the $6^{\text {th }}$ week of exposure. In samples exposed to CdVA, the ALT production levels in the liver indicated that T4 in both $2^{\text {nd }}$ and $4^{\text {th }}$ weeks of exposure, respectively are significantly higher than other treatments. The T3 and T2 mean in the $6^{\text {th }}$ and $8^{\text {th }}$ weeks of exposure, respectively are significantly higher than other treatments. The highest mean ALT produced in the liver was $73.48 \pm 0.15 \mathrm{nM} / \mathrm{mgobtained}$ in $T 3$ at the end of the $6^{\text {th }}$ week of exposure.T2 and Tlin the kidneys of the samples at the end of the $2^{\text {nd }}$ and $4^{\text {th }}$ weeks of exposure, respectively are significantly higher than other treatments. T1 in both $6^{\text {th }}$ and $8^{\text {th }}$ weeks of exposure,respectively are significantly higher than other treatments. $T 1$ recorded the highest ALT value of $81.61 \pm 0.15 \mathrm{nM} / \mathrm{mgin}$ the kidney of the samples at the $4^{\text {th }}$ week of exposure. The T2 and T4 in the gills of the samples in the $2^{\text {nd }}$ and $4^{\text {th }}$ weeks of exposure, respectively are significantly higher than other treatments. InT3 and T4 in the $6^{\text {th }}$ and $8^{\text {th }}$ weeks of exposure, respectively are significantly higher than other treatments. The highest ALT produced in the gill of the fish was $66.61 \pm 0.10 \mathrm{nM} / \mathrm{mgobtained}$ in T4 at the $4^{\text {th }}$ week of exposure. In samples exposed toCdVC, the ALT levels in the liver indicated that T3 and T4 in the $2^{\text {nd }}$ and $4^{\text {th }}$ weeks of exposure, respectively are significantly higher than other treatments. The T3 in both $6^{\text {th }}$ and $8^{\text {th }}$ weeks of exposure, respectively are significantly higher than other treatments. $T 1$ in both $10^{\text {th }}$ and $12^{\text {th }}$ weeks of exposure are significantly higher than other treatments. The highest ALT produced in the liver was60.43 $\pm 0.15 \mathrm{nM} / \mathrm{mg}$ obtained in T3 at the $6^{\text {th }}$ week of exposure. In the kidney's Tlin both $2^{\text {nd }}$ and $4^{\text {th }}$ weeks of exposure, respectively are significantly higher than other treatments.T3 and T2 in the kidneys of the samples at the 6 th and $8^{\text {th }}$ weeks of exposure, respectively are significantly higher than other treatments. The T3 and T1 in the $10^{\text {th }}$ and $12^{\text {th }}$ weeks of exposure, respectively are significantly higher than other treatments. The highest ALT in the kidney was $56.19 \pm 0.15 \mathrm{nM} / \mathrm{mgobtained}$ in T3 at the $6^{\text {th }}$ week of exposure.The $T 1$ and T3 in the gills of the samples in the $2^{\text {nd }}$ and $4^{\text {th }}$ weeks of exposure, respectively are significantly higher than other treatments. $T 1$ in both $6^{\text {th }}$ and $8^{\text {th }}$ weeks of exposure, respectively are significantly higher than other treatments. T3 and T2 are significantly higher than other treatments in the $10^{\text {th }}$ and $12^{\text {th }}$ weeks of exposure. The highest ALT produced in the gillwas $65.17 \pm 0.15 \mathrm{nM} / \mathrm{mgobtained}$ in $T 3$ at the $10^{\text {th }}$ week of exposure. In samples exposed to CdVE, the ALT in the liver indicated that $T 2$ in both $2^{\text {nd }}$ and $4^{\text {th }}$ weeks of exposure, respectively are significantly higher than other treatments. The T2 and $T 1$ in the $6^{\text {th }}$ and $8^{\text {th }}$ weeks of exposure, respectively are significantly higher than other treatments. T1 in both $10^{\text {th }}$ and $12^{\text {th }}$ weeks of exposure are significantly higher than other treatments.
\end{abstract}

Keywords: Clariasgariepinus, Fish organs, ALT production levels, Ameliorative roles, vitamin supplements and Cd treatments 


\section{INTRODUCTION}

Fish is a rich source of animal protein throughout the world. Due to its nutritional value (Tingmanet al., 2010); the demand for fish food has been on the increase with increasing human population (FAO 2010, 2012).African catfish, Clariasgariepinusis an important commercial fish due to its high growth rate, high consumer acceptability, and ability to withstand poor water quality, and oxygen depletion (Adewoluet al., 2008; Karamiet al., 2010).The African cat fish, Clariasgariepinus is a tropical hardy species belonging to the Phylum Chordata,class Actinopterygii and family Clariidae. Clariasspecies is a widely distributed fish in Asia and Africa. In these areas, the fish is extremely popular on account of its tasty flesh, its unparalleled hardness, its rapid growth and its somewhat acceptable market price (FAO, 2003).In Nigeria, Clariasspecies is an indigenous fish occurring in freshwater throughout the country. It is suspected that apart from tilapia, Clariasis the most abundant cultivated fish species in Nigeria (FAO, 2003). The common species found are Clariasgariepinus, Clariasanguillaris, Clariasbuthupogon and Clariaslazera.

The presence of pollutants in the environment of an aquatic organism such as fish can lead to the production of reactive oxygen species and consequently, oxidative stress. Heavy metals are known to elicit oxidative stress in organisms when the threshold is exceeded. Heavy metals are also known to promote oxidative damage by increasing the cellular concentration of reactive oxygen species (ROS) in fish, consequently, a response of antioxidativedefences (Monteiroet al., 2010).Heavy metals could be essential or non-essential. Heavy metals such as $\mathrm{Fe}, \mathrm{Cu}, \mathrm{Zn}, \mathrm{Ni}, \mathrm{Co}, \mathrm{Cr}$, and $\mathrm{Mn}$ are vital to human only at lower concentrations, but they become more toxic when theyare taken up more than the biorecommended limits (Shilpiet al., 2015). It is also known that even essential metals may be toxic on the biologicalactivities of organisms above certain concentrations (Merciaiet al.,2014).Fish are particularly vulnerable and heavily exposed to pollutants due to feeding and living in aquatic ecosystems, because they cannot avoid pollutant harmful effects (Ahmed et al., 2020). Heavy metals enter fish by direct absorption from water through their gills and skin, or by ingestion of contaminated food (Ayyatet al., 2020).Heavy metals induce significant damage to the physiologic and biochemical processes of the fish and subsequently to fish consumers (Mehanaet al., 2020).

Among all the heavy metals, $\mathrm{Cd}$, arsenic, mercury and lead pose highest degree of toxicity and that is of great concern to plants and human health (Atharet al., 2018). Antioxidant enzymes are crucial in their effort to decrease oxidative stress produced by exposure to toxicants (Saglamet al., 2014). It has also been reported that antioxidant may ameliorate, protect and remove the oxidative damage to a target organ or molecule (El-Shenawy and Al-Ghamdi, 2014).

Vitamins $\mathrm{A}, \mathrm{C}$ and $\mathrm{E}$ are known to play ameliorative roles in the attenuation of the effects of pollutants on organisms. Also, Vitamins C and E supplementationshave been reported to play a positive role in detoxification of mercury toxicity especially at lowerconcentrations (Thakur and Kanshere, 2014). Vitamin $C$ is known to play a crucial role in the immunological and antioxidant properties of vertebrates capable of maintaining the integrity, fluidity of membranes and capable of controlling the oxidizing reactions of fatty acids, thus keeping cellular respiration and avoiding cell death (Abdel-Warithet al., 2011).Non-enzymatic antioxidants such as vitamins $\mathrm{C}$ and $\mathrm{E}$ can also act to overcome oxidative stress, being a part of the total antioxidant system. They prevent the increased production of free radicals induced by oxidative damage to lipids and lipoproteins in various cellular compartments and tissues. The main biological function of vitamin $\mathrm{E}$ is its direct influence on cellular responses to oxidative stress through modulation of signal transduction pathway (Pratt et al., 2010). Vitamins $\mathrm{E}$ and $\mathrm{C}$ supplementation can induce protective effects on certain conditions after free radical-mediated cellular damage or disruption (Yolanda and Maria, 2012). Vitamin E ( $\alpha$-tocopherol) is a fat soluble antioxidant that inhibits the production of reactive oxygen species formed when fat undergoes oxidation.

Aspartate aminotransferase (AST) and alanine aminotransferase (ALT) belong to theplasma nonfunctional enzymes which are normally localized within the cells of liver, heart,gills, kidneys, muscle and other organs. These enzymes are liberated into the blood in pathological situations and therefore are of clinical importance. AST and ALT are highly conservative indicators inliver, and are commonly located in hepatic cytoplasm and wouldrelease into the circulation when hepatocytes necrotize (Arenas et al., 2017). The presence of pollutant can trigger the utilization or increased 
production of AST and ALT. For instance, cadmium in plasma ofgoldfish significantly increased the activities of plasma glutamic acid oxaloacetic acid-transaminase (GOT) and glutamic acid-pyruvic acid transaminase (GPT) (Zikicet al., 2001).

The ameliorative role of vitamins was evident when Vitamin $\mathrm{E}$ and metallothionein treatments protected against Cd-induced damage of liver in grass carp by decreasing AST and ALT content, repairing organelles, and maintained the antioxidant system by elevating CAT, SOD, and GSH-Px activity and regulating related mRNA transcript expression (Fenget al., 2018). Furthermore,increased activities of AST, ALT and ALP in Indian major carps exposed to nitrite toxicity have been recorded (Das et al., 2004).This research therefore, addresses the effects of Cd toxicant on ALT production levels and how such effects can be attenuated to certain extent by administration of vitamin supplements.

\section{Materials ANd Methods}

\subsection{Samples/Materials Collection and Acclimatization}

A total number of seven hundred and fifty (750) fingerlings of C.gariepinuswere purchased from a commercial fish farmer and transported in 50L containers filled with water to the Old Farm Research Unit of the Department of Water, Aquaculture and Fisheries Technology, Bosso Campus, Federal University of Technology, Minna, Nigeria. The fishes were placed in fish ponds with water for acclimatization. The fishes were fed to satiation twice daily(morning and evening) with Blue Crown feed $(3 \mathrm{~mm})$ for 14 days $(2$ weeks) for the acclimatization. The holding water was changed every 3 days during the period.

The vitamins A, C and $\mathrm{E}$ granules or pellets (500g each) were purchased from commercial chemical stores. The toxicant, $\mathrm{Cd}$ (2 units of $100 \mathrm{~g}$ ) analar grades were purchased from commercial chemical stores and stored in a cool dry condition throughout the period of the experiment. This toxicant was administered according to the sub-lethal concentrations of the treatments during the chronic phase of the exposure.

\subsection{Experimental Set-up}

Five treatments including control with two replicates in each treatment were set-up for the $\mathrm{Cd}$, Vitamin A, C and E; and the sub-lethal exposures were run for a period of twelve (12) weeks. The treatments are $0 \%$ (control), $15 \%, 20 \%, 25 \%$ and $30 \%$ which translated into $12 \mathrm{mg} / \mathrm{L}, 16 \mathrm{mg} / \mathrm{L}$, $20 \mathrm{mg} / \mathrm{L}$ and $24 \mathrm{mg} / \mathrm{L}$ of the $\mathrm{LC}_{50}$, respectively. The groups of treatments were tagged $\mathrm{Cd}(\mathrm{Cd}$ only with T1-T4 and replicates), second CdVA (Cd+vitamin A with T1-T4 and replicates), third CdVC (Cd+vitamin C with T1-T4 and replicates) and fourth CdVE (Cd+vitamin E with T1-T4 and replicates).Each treatmentwas in two replicates containing 20 fish in $20 \mathrm{~L}$ plastic aquarium for the $\mathrm{Cd}$, Vitamins $\mathrm{A}, \mathrm{C}$ and $\mathrm{E}$ supplemented exposures. The water was changed and fresh toxicant and the vitamins with the same set of concentrations were added every 72 hours according to Organization for Economic Co-operation and Development (OECD, 2007) standards. Three fish samples were picked at random and sacrificed from each trough on every $14^{\text {th }}$ day for the twelve weeks exposure period. The liver, gills and kidney were excised, homogenized in sodium phosphate buffer solution using ceramic mortar and pestle; and stored in sample tubes, then refrigerated until needed for analyses of ALT.

\subsection{Preparation of Sodium Phosphate Buffer}

Sodium phosphate buffer solution $(0.2 \mathrm{M})$ was prepared from the mixture of sodium dihydrogen orthophosphate with $0.1 \mathrm{M}$ and disodium hydrogen orthophosphate with $0.1 \mathrm{M}$. The pHwas adjusted to 8.0 .

\subsection{Alanine Aminotransferase (ALT)Determination}

Fish tissues ALT were determined as described by Reitman and Frankel (1957)from all the treatments and replicates. Spectrophotometric method was used for the assay of alanine aminotransferase. The homogenates were prepared in the laboratories as follow: $100 \mu \mathrm{l}(0.1 \mathrm{ml})$ of the tissue homogenate was added into test tubes with $500 \mu \mathrm{l}(0.5 \mathrm{ml})$ of reagent 1 (buffer). The mixture was incubated for 30 minutes at $37^{\circ} \mathrm{C}$ in samples of C. griepinus analyzed for ALT. Subsequently, $500 \mu 1(0.5 \mathrm{ml})$ of reagent $2\left(2,4\right.$ - dinitrophenylhydrazine) was added and kept for 20 minutes at $25^{\circ} \mathrm{C}$. The reaction was 
terminated with the addition of $5000 \mu 1(5.0 \mathrm{ml})$ of $0.4 \mathrm{Mol} / \mathrm{L} \mathrm{NaOH}$ to the mixture. The blank was prepared with $500 \mu \mathrm{l}(0.5 \mathrm{ml})$ of reagent 1 and $0.1 \mu \mathrm{l}(100 \mu \mathrm{l})$ of distilled water. The absorbance in each case was read at $546 \mathrm{~nm}$.

\subsection{Data Analyses}

The antioxidants levels in samples exposed to sub-lethal concentrations of the toxicants as well as those treatments supplemented with vitamins were analysed using One Way Analysis of Variance followed by Duncan Multiple Range Test to separate the means where significant atP $\leq 0.05$ level of significanceusing SPSS Statistical Package (version 20.0 for Windows).

\section{RESULTS AND DISCUSSIONS}

ALT production levels in Liver, Kidneys and gills of C. gariepinus exposed to sub-lethal concentrations of $\mathrm{CdCl}_{2}$ toxicant and the respective supplemented treatments with Vitamins $\mathrm{A}, \mathrm{C}$ and E for a period of twelve weeks and sampled fortnightly

From the results of the samples exposed to sub-lethal concentrations of $\mathrm{CdCl}_{2}$, the ALT production levels in the liver of the fish showed that T1 and T4 mean values in the $2^{\text {nd }}$ and $4^{\text {th }}$ weeks of exposure, respectively are significantly higher than other treatments including the control. The control mean values in the $6^{\text {th }}$ and $8^{\text {th }}$ weeks of exposure, respectively are significantly higher than other treatments. T1mean values in the $10^{\text {th }}$ week of exposure are significantly higher than other treatments. The highest mean value of ALT produced in the liver was $65.43 \pm 0.10 \mathrm{nM} / \mathrm{mg}$ obtained in T4 at the end of the $6^{\text {th }}$ week of exposure. (Table 3.1). Furthermore, T1 and T4 mean values in the kidneys of the samples at the end of the $2^{\text {nd }}$ and $4^{\text {th }}$ weeks of exposure, respectively are significantly higher than other treatments. The control mean values in the $6^{\text {th }}$ and $10^{\text {th }}$ weeks of exposure are significantly higher than other treatments. T4 mean values in the $8^{\text {th }}$ week of exposure are significantly higher than other treatments including the control. T4 mean value in the $4^{\text {th }}$ week of exposure recorded the highest ALT production value of $71.87 \pm 0.20 \mathrm{nM} / \mathrm{mgin}$ the kidney of the samples. (Table 3.2).In addition to the forgoing, the T3 and T4 mean values in the gills of the samples in the $2^{\text {nd }}$ and $4^{\text {th }}$ weeks of exposure are significantly higher than other treatments. In like manner, T2 mean values in the $6^{\text {th }}$ week of exposure are significantly higher than other treatments. The control mean values in the $8^{\text {th }}$ and $10^{\text {th }}$ weeks of exposure, respectively are significantly higher than other treatments. The highest mean value of ALT produced in the gill of the fish was $62.97 \pm 0.05 \mathrm{nM} / \mathrm{mgobtained}$ in T2 at the end of the $6^{\text {th }}$ week of exposure. (Table 3.3).

Table3.1. ALT production levels in the Liver of C. gariepinus exposed to sub-lethal concentrations of CdCl $\mathrm{for}$ a period of 12 weeks

\begin{tabular}{|l|l|l|l|l|l|l|}
\hline & $\mathbf{1}^{\text {st }}$ & $\mathbf{2}^{\text {nd }}$ & $\mathbf{3}^{\text {rd }}$ & $\mathbf{4}^{\text {th }}$ & $\mathbf{5}^{\text {th }}$ & $\mathbf{6}^{\text {th }}$ \\
\hline CR & $48.48 \pm 0.20^{\mathrm{n}}$ & $8.73 \pm 0.15^{\mathrm{d}}$ & $66.70 \pm 0.05^{\mathrm{n}}$ & $65.17 \pm 0.05^{\mathrm{o}}$ & $48.90 \pm 0.15^{\mathrm{e}}$ & $23.13 \pm 0.15^{\mathrm{c}}$ \\
\hline T1 & $38.39 \pm 0.05^{\mathrm{1}}$ & $6.19 \pm 0.15^{\mathrm{b}}$ & $61.36 \pm 0.10^{\mathrm{j}}$ & $7.50 \pm 0.10^{\mathrm{e}}$ & $58.56 \pm 0.15^{\mathrm{h}}$ & $65.34 \pm 0.05^{\mathrm{f}}$ \\
\hline T2 & $12.71 \pm 0.10^{\mathrm{f}}$ & $50.68 \pm 0.10^{\mathrm{k}}$ & $41.78 \pm 0.05^{\mathrm{e}}$ & $5.93 \pm 0.20^{\mathrm{d}}$ & $0.00 \pm 0.00$ & $0.00 \pm 0.00$ \\
\hline T3 & $4.41 \pm 0.20^{\mathrm{b}}$ & $25.85 \pm 0.15^{\mathrm{g}}$ & $53.31 \pm 0.15^{\mathrm{h}}$ & $2.37 \pm 0.10^{\mathrm{c}}$ & $53.39 \pm 0.20^{\mathrm{f}}$ & $0.00 \pm 0.00$ \\
\hline T4 & $11.36 \pm 0.10^{\mathrm{e}}$ & $51.36 \pm 0.10^{1}$ & $65.43 \pm 0.10^{\mathrm{m}}$ & $2.20 \pm 0.20^{\mathrm{b}}$ & $0.00 \pm 0.00$ & $0.00 \pm 0.00$ \\
\hline
\end{tabular}

Mean values and standard errors with different alphabets along the column are significantly different from each other at $P \leq 0.05$. The unit for ALT mean value in each case isnM/mg.

Table3.2. ALT production levels in the Kidney of C. gariepinus exposed to sub-lethal concentrations of CdCl $\mathrm{Cl}_{2}$ for a period of 12 weeks

\begin{tabular}{|l|l|l|l|l|l|l|}
\hline & $\mathbf{1}^{\text {st }}$ & $\mathbf{2}^{\text {nd }}$ & $\mathbf{3}^{\text {rd }}$ & $\mathbf{4}^{\text {th }}$ & $\mathbf{5}^{\text {th }}$ & $\mathbf{6}^{\text {th }}$ \\
\hline CR & $65.68 \pm 0.15^{\mathrm{o}}$ & $21.87 \pm 0.10^{\mathrm{f}}$ & $68.39 \pm 0.15^{\mathrm{o}}$ & $12.54 \pm 0.10^{\mathrm{h}}$ & $54.32 \pm 0.05^{\mathrm{g}}$ & $16.10 \pm 0.10^{\mathrm{a}}$ \\
\hline T1 & $47.63 \pm 0.10^{\mathrm{m}}$ & $31.02 \pm 0.10^{\mathrm{h}}$ & $48.82 \pm 0.20^{\mathrm{f}}$ & $11.27 \pm 0.05^{\mathrm{g}}$ & $46.19 \pm 0.15^{\mathrm{d}}$ & $35.59 \pm 0.10^{\mathrm{e}}$ \\
\hline T2 & $32.71 \pm 0.20^{\mathrm{j}}$ & $58.14 \pm 0.10^{\mathrm{m}}$ & $61.70 \pm 0.10^{\mathrm{k}}$ & $14.92 \pm 0.20^{\mathrm{i}}$ & $0.00 \pm 0.00$ & $0.00 \pm 0.00$ \\
\hline T3 & $6.87 \pm 0.15^{\mathrm{c}}$ & $63.48 \pm 0.05^{\mathrm{n}}$ & $22.63 \pm 0.15^{\mathrm{d}}$ & $9.32 \pm 0.10^{\mathrm{f}}$ & $15.43 \pm 0.20^{\mathrm{a}}$ & $0.00 \pm 0.00$ \\
\hline T4 & $12.97 \pm 0.15^{\mathrm{g}}$ & $71.87 \pm 0.20^{\mathrm{o}}$ & $13.75 \pm 0.01^{\mathrm{b}}$ & $46.44 \pm 0.10^{\mathrm{n}}$ & $0.00 \pm 0.00$ & $0.00 \pm 0.00$ \\
\hline
\end{tabular}

Mean values and standard errors with different alphabets along the column are significantly different from each other at $P \leq 0.05$. The unit for ALT mean value in each case isnM/mg. 
Table3.3. ALT production levels in the Gill of C. gariepinus exposed to sub-lethal concentrations of $C d C l_{2}$ for a period of 12 weeks

\begin{tabular}{|l|l|l|l|l|l|l|}
\hline & $\mathbf{1}^{\text {st }}$ & $\mathbf{2}^{\text {nd }}$ & $\mathbf{3}^{\text {rd }}$ & $\mathbf{4}^{\text {th }}$ & $\mathbf{5}^{\text {th }}$ & $\mathbf{6}^{\text {th }}$ \\
\hline $\mathbf{C R}$ & $26.61 \pm 0.20^{\mathrm{i}}$ & $10.68 \pm 0.20^{\mathrm{e}}$ & $7.80 \pm 0.10^{\mathrm{a}}$ & $19.32 \pm 0.10^{\mathrm{m}}$ & $77.37 \pm 0.05$ & $24.49 \pm 0.05^{\mathrm{d}}$ \\
\hline $\mathbf{T}_{\mathbf{1}}$ & $7.97 \pm 0.20^{\mathrm{d}}$ & $43.82 \pm 0.05^{\mathrm{i}}$ & $58.05 \pm 0.05^{\mathrm{i}}$ & $19.07 \pm 0.15^{\mathrm{l}}$ & $37.46 \pm 0.10^{\mathrm{c}}$ & $21.87 \pm 1.37^{\mathrm{b}}$ \\
\hline $\mathbf{T}_{\mathbf{2}}$ & $2.04 \pm 0.10^{\mathrm{a}}$ & $7.12 \pm 0.10^{\mathrm{c}}$ & $62.97 \pm 0.05^{\mathrm{l}}$ & $0.51 \pm 0.10^{\mathrm{a}}$ & $0.00 \pm 0.00$ & $0.00 \pm 0.00$ \\
\hline $\mathbf{T}_{\mathbf{3}}$ & $33.82 \pm 0.15^{\mathrm{k}}$ & $0.42 \pm 0.05^{\mathrm{a}}$ & $13.82 \pm 0.15^{\mathrm{c}}$ & $17.97 \pm 0.10^{\mathrm{k}}$ & $19.49 \pm 0.10^{\mathrm{b}}$ & $0.00 \pm 0.00$ \\
\hline $\mathbf{T}_{\mathbf{4}}$ & $21.61 \pm 0.05^{\mathrm{h}}$ & $45.26 \pm 0.10^{\mathrm{j}}$ & $50.26 \pm 0.15^{\mathrm{g}}$ & $16.02 \pm 0.05^{\mathrm{j}}$ & $0.00 \pm 0.00$ & $0.00 \pm 0.00$ \\
\hline
\end{tabular}

Mean values and standard errors with different alphabets along the column are significantly different from each other at $P \leq 0.05$. The unit for ALT mean value in each case isnM/mg.

From the results of the samples exposed to sub-lethal concentrations of $\mathrm{CdCl}_{2}$, and supplemented with vitamin A, the ALT production levels in the liver of the fish indicated that T4 mean values in both $2^{\text {nd }}$ and $4^{\text {th }}$ weeks of exposure, respectively are significantly higher than other treatments. The T3 and T2 mean values in the $6^{\text {th }}$ and $8^{\text {th }}$ weeks of exposure, respectively are significantly higher than other treatments. The highest mean value of ALT produced in the liver was73.48 $\pm 0.15 \mathrm{nM} / \mathrm{mgobtained}$ in $\mathrm{T} 3$ at the end of the $6^{\text {th }}$ week of exposure. (Table 3.4). Furthermore, T2 and T1 mean values in the kidneys of the samples at the end of the $2^{\text {nd }}$ and $4^{\text {th }}$ weeks of exposure, respectively are significantly higher than other treatments. T1 mean value in both $6^{\text {th }}$ and $8^{\text {th }}$ weeks of exposure,respectively are significantly higher than other treatments. T1 recorded the highest ALT production value of $81.61 \pm 0.15 \mathrm{nM} / \mathrm{mgin}$ the kidney of the samples at the end of the $4^{\text {th }}$ week of exposure. (Table 3.5).In addition to the forgoing, the T2 and T4 mean values in the gills of the samples in the $2^{\text {nd }}$ and $4^{\text {th }}$ weeks of exposure, respectively are significantly higher than other treatments. In like manner, T3 and T4 mean values in the $6^{\text {th }}$ and $8^{\text {th }}$ weeks of exposure, respectively are significantly higher than other treatments. The highest mean value of ALT produced in the gill of the fish was $66.61 \pm 0.10 \mathrm{nM} / \mathrm{mgobtained}$ in $\mathrm{T} 4$ at the end of the $4^{\text {th }}$ week of exposure. (Table 3.6).

Table3.4. ALT production levels in the Liver of C. gariepinus exposed to sub-lethal concentrations of $\mathrm{CdCl}_{2}$ and supplemented with vitamin A for a period of 12 weeks

\begin{tabular}{|l|l|l|l|l|l|l|}
\hline & $\mathbf{1}^{\text {st }}$ & $\mathbf{2}^{\text {nd }}$ & $\mathbf{3}^{\text {rd }}$ & $\mathbf{4}^{\text {th }}$ & $\mathbf{5}^{\text {th }}$ & $\mathbf{6}^{\text {th }}$ \\
\hline CR & $48.48 \pm 0.20^{\mathrm{m}}$ & $8.73 \pm 0.15^{\mathrm{c}}$ & $66.70 \pm 0.05^{1}$ & $65.17 \pm 0.05^{\mathrm{o}}$ & $48.90 \pm 0.15^{\mathrm{a}}$ & $23.14 \pm 0.15^{\mathrm{b}}$ \\
\hline T1 & $22.63 \pm 0.15^{\mathrm{a}}$ & $8.48 \pm 0.10^{\mathrm{b}}$ & $64.15 \pm 0.05^{\mathrm{k}}$ & $2.04 \pm 0.20^{\mathrm{b}}$ & $0.00 \pm 0.00$ & $0.00 \pm 0.00$ \\
\hline T2 & $29.41 \pm 0.15^{\mathrm{g}}$ & $40.17 \pm 0.20^{\mathrm{i}}$ & $0.00 \pm 0.00$ & $15.43 \pm 0.20^{\mathrm{j}}$ & $0.00 \pm 0.00$ & $0.00 \pm 0.00$ \\
\hline T3 & $23.31 \pm 0.15^{\mathrm{b}}$ & $22.88 \pm 0.10^{\mathrm{g}}$ & $73.48 \pm 0.15^{\mathrm{n}}$ & $10.76 \pm 0.15^{\mathrm{g}}$ & $0.00 \pm 0.00$ & $0.00 \pm 0.00$ \\
\hline T4 & $40.76 \pm 0.05^{\mathrm{k}}$ & $49.41 \pm 0.15^{\mathrm{j}}$ & $27.88 \pm 0.15^{\mathrm{c}}$ & $5.43 \pm 0.10^{\mathrm{e}}$ & $0.00 \pm 0.00$ & $0.00 \pm 0.00$ \\
\hline
\end{tabular}

Mean values and standard errors with different alphabets along the column are significantly different from each other at $P \leq 0.05$. The unit for ALT mean value in each case isnM/mg.

Table3.5. ALT production levels in the Kidney of C. gariepinus exposed to sub-lethal concentrations of $\mathrm{CdCl}_{2}$ and supplemented with vitamin A for a period of 12 weeks

\begin{tabular}{|l|l|l|l|l|l|l|}
\hline & $\mathbf{1}^{\text {st }}$ & $\mathbf{2}^{\text {nd }}$ & $\mathbf{3}^{\text {rd }}$ & $\mathbf{4}^{\text {th }}$ & $\mathbf{5}^{\text {th }}$ & $\mathbf{6}^{\text {th }}$ \\
\hline CR & $65.68 \pm 0.15^{\mathrm{o}}$ & $21.87 \pm 0.10^{\mathrm{f}}$ & $68.39 \pm 0.15^{\mathrm{m}}$ & $12.54 \pm 0.10^{\mathrm{i}}$ & $54.32 \pm 0.05^{\mathrm{b}}$ & $16.10 \pm 0.10^{\mathrm{a}}$ \\
\hline T1 & $32.04 \pm 0.10^{\mathrm{i}}$ & $81.61 \pm 0.15^{\mathrm{n}}$ & $61.70 \pm 0.10^{\mathrm{j}}$ & $38.56 \pm 0.05^{\mathrm{n}}$ & $0.00 \pm 0.00$ & $0.00 \pm 0.00$ \\
\hline T2 & $43.14 \pm 0.24^{\mathrm{1}}$ & $8.73 \pm 0.15^{\mathrm{c}}$ & $43.48 \pm 0.15^{\mathrm{f}}$ & $0.51 \pm 0.00^{\mathrm{a}}$ & $0.00 \pm 0.00$ & $0.00 \pm 0.00$ \\
\hline T3 & $36.61 \pm 0.10^{\mathrm{j}}$ & $21.19 \pm 0.10^{\mathrm{e}}$ & $56.36 \pm 0.05^{\mathrm{h}}$ & $38.05 \pm 0.05^{\mathrm{m}}$ & $0.00 \pm 0.00$ & $0.00 \pm 0.00$ \\
\hline T4 & $24.66 \pm 0.05^{\mathrm{d}}$ & $5.85 \pm 0.15^{\mathrm{a}}$ & $58.39 \pm 0.15^{\mathrm{i}}$ & $4.24 \pm 0.10^{\mathrm{c}}$ & $0.00 \pm 0.00$ & $0.00 \pm 0.00$ \\
\hline
\end{tabular}

Mean values and standard errors with different alphabets along the column are significantly different from each other at $P \leq 0.05$. The unit for ALT mean value in each case isnM/mg.

Table3.6. ALT production levels in the Gill of C. gariepinus exposed to sub-lethal concentrations of CdCl $\mathrm{and}$ supplemented with vitamin A for a period of 12 weeks

\begin{tabular}{|l|l|l|l|l|l|l|}
\hline & $1^{\text {st }}$ & $2^{\text {nd }}$ & $3^{\text {rd }}$ & $4^{\text {th }}$ & $5^{\text {th }}$ & $6^{\text {th }}$ \\
\hline CR & $26.61 \pm 0.20^{\mathrm{e}}$ & $10.68 \pm 0.20^{\mathrm{d}}$ & $7.80 \pm 0.10^{\mathrm{a}}$ & $19.32 \pm 0.10^{\mathrm{k}}$ & $77.37 \pm 0.05^{\mathrm{c}}$ & $24.49 \pm 0.05^{\mathrm{c}}$ \\
\hline $\mathrm{T}_{1}$ & $31.87 \pm 0.20^{\mathrm{h}}$ & $53.14 \pm 0.15^{\mathrm{l}}$ & $20.00 \pm 0.10^{\mathrm{b}}$ & $9.07 \pm 0.15^{\mathrm{f}}$ & $0.00 \pm 0.00$ & $0.00 \pm 0.00$ \\
\hline $\mathrm{T}_{2}$ & $57.12 \pm 0.10^{\mathrm{n}}$ & $23.31 \pm 0.15^{\mathrm{h}}$ & $28.14 \pm 0.10^{\mathrm{d}}$ & $5.17 \pm 0.15^{\mathrm{d}}$ & $0.00 \pm 0.00$ & $0.00 \pm 0.00$ \\
\hline $\mathrm{T}_{3}$ & $29.32 \pm 0.20^{\mathrm{f}}$ & $49.58 \pm 0.15^{\mathrm{k}}$ & $52.46 \pm 0.15^{\mathrm{g}}$ & $10.93 \pm 0.15^{\mathrm{h}}$ & $0.00 \pm 0.00$ & $0.00 \pm 0.00$ \\
\hline $\mathrm{T}_{4}$ & $23.39 \pm 0.10^{\mathrm{c}}$ & $66.61 \pm 0.10^{\mathrm{m}}$ & $38.82 \pm 0.10^{\mathrm{e}}$ & $33.56 \pm 0.20^{\mathrm{l}}$ & $0.00 \pm 0.00$ & $0.00 \pm 0.00$ \\
\hline
\end{tabular}

Mean values and standard errors with different alphabets along the column are significantly different from each other at $P \leq 0.05$. The unit for ALT mean value in each case isnM/mg. 
From the results of the samples exposed to sub-lethal concentrations of $\mathrm{CdCl}_{2}$, and supplemented with vitamin C, the ALT production levels in the liver of the fish indicated that T3 and T4 mean values in the $2^{\text {nd }}$ and $4^{\text {th }}$ weeks of exposure, respectively are significantly higher than other treatments. The T3 mean values in both $6^{\text {th }}$ and $8^{\text {th }}$ weeks of exposure, respectively are significantly higher than other treatments. Likewise, $\mathrm{T} 1$ mean values in both $10^{\text {th }}$ and $12^{\text {th }}$ weeks of exposure are significantly higher than other treatments. The highest mean value of ALT produced in the liver was $60.43 \pm 0.15 \mathrm{nM} / \mathrm{mg}$ obtained in $\mathrm{T} 3$ at the end of the $6^{\text {th }}$ week of exposure. (Table 3.7). In another development, kidney's T1 mean values in both $2^{\text {nd }}$ and $4^{\text {th }}$ weeks of exposure, respectively are significantly higher than other treatments. Also, T3 and T2 mean values in the kidneys of the samples at the end of both 6 th and $8^{\text {th }}$ weeks of exposure, respectively are significantly higher than other treatments. The T3 and T1 mean values in the $10^{\text {th }}$ and $12^{\text {th }}$ weeks of exposure, respectively are significantly higher than other treatments. The highest ALT production value of $56.19 \pm 0.15 \mathrm{nM} / \mathrm{mgin}$ the kidney of the samples was obtained in $\mathrm{T} 3$ at the end of the $6^{\text {th }}$ week of exposure. (Table 3.8).In addition to the forgoing, the T1 and T3 mean values in the gills of the samples in the $2^{\text {nd }}$ and $4^{\text {th }}$ weeks of exposure, respectively are significantly higher than other treatments. T1 mean values in both $6^{\text {th }}$ and $8^{\text {th }}$ weeks of exposure, respectively are significantly higher than other treatments. Likewise, T3 and T2 mean values are significantly high than other treatments in the $10^{\text {th }}$ and $12^{\text {th }}$ weeks of exposure. The highest mean value of ALT produced in the gill of the fish was $65.17 \pm 0.15 \mathrm{nM} / \mathrm{mgobtained}$ in T3 at the end of the $10^{\text {th }}$ week of exposure. (Table 3.9).

Table3.7. ALT production levels in the Liver of C. gariepinus exposed to sub-lethal concentrations of CdCl ${ }_{2}$ and supplemented with vitamin $C$ for a period of 12 weeks

\begin{tabular}{|l|l|l|l|l|l|l|}
\hline & $1^{\text {st }}$ & $2^{\text {nd }}$ & $3^{\text {rd }}$ & $4^{\text {th }}$ & $5^{\text {th }}$ & $6^{\text {th }}$ \\
\hline CR & $48.48 \pm 0.20^{\mathrm{n}}$ & $8.73 \pm 0.15^{\mathrm{d}}$ & $66.70 \pm 0.05^{\mathrm{l}}$ & $65.17 \pm 0.05^{\mathrm{n}}$ & $48.90 \pm 0.15^{\mathrm{g}}$ & $23.14 \pm 0.15^{\mathrm{e}}$ \\
\hline T1 & $29.75 \pm 0.05^{\mathrm{k}}$ & $7.29 \pm 0.10^{\mathrm{c}}$ & $60.00 \pm 0.10^{\mathrm{j}}$ & $9.15 \pm 0.10^{\mathrm{b}}$ & $57.29 \pm 0.10^{\mathrm{j}}$ & $22.97 \pm 0.24^{\mathrm{d}}$ \\
\hline T2 & $13.22 \pm 0.20^{\mathrm{c}}$ & $9.32 \pm 0.10^{\mathrm{e}}$ & $0.00 \pm 0.00$ & $15.51 \pm 0.15^{\mathrm{g}}$ & $9.75 \pm 0.05^{\mathrm{a}}$ & $19.32 \pm 0.10^{\mathrm{c}}$ \\
\hline T3 & $40.17 \pm 0.10^{\mathrm{m}}$ & $13.82 \pm 0.15^{\mathrm{j}}$ & $60.43 \pm 0.15^{\mathrm{k}}$ & $32.04 \pm 0.10^{\mathrm{j}}$ & $45.00 \pm 0.05^{\mathrm{f}}$ & $0.00 \pm 0.00$ \\
\hline T4 & $34.49 \pm 0.05^{\mathrm{l}}$ & $26.53 \pm 0.15^{\mathrm{m}}$ & $53.39 \pm 0.20^{\mathrm{h}}$ & $15.00 \pm 0.15^{\mathrm{f}}$ & $0.00 \pm 0.00$ & $0.00 \pm 0.00$ \\
\hline
\end{tabular}

Mean values and standard errors with different alphabets along the column are significantly different from each other at $P \leq 0.05$. The unit for ALT mean value in each case isnM/mg.

Table3.8. ALT production levels in the Kidney of C. gariepinus exposed to sub-lethal concentrations of CdCl 2 and supplemented with vitamin $C$ for a period of 12 weeks

\begin{tabular}{|l|l|l|l|l|l|l|}
\hline & $1^{\text {st }}$ & $2^{\text {nd }}$ & $3^{\text {rd }}$ & $4^{\text {th }}$ & $5^{\text {th }}$ & $6^{\text {th }}$ \\
\hline CR & $65.68 \pm 0.15^{\mathrm{o}}$ & $21.87 \pm 0.10^{\mathrm{l}}$ & $68.39 \pm 0.15^{\mathrm{m}}$ & $12.54 \pm 0.10^{\mathrm{d}}$ & $54.32 \pm 0.05^{\mathrm{i}}$ & $16.10 \pm 0.10^{\mathrm{a}}$ \\
\hline T1 & $23.73 \pm 0.10^{\mathrm{g}}$ & $49.58 \pm 0.05^{\mathrm{o}}$ & $51.19 \pm 0.10^{\mathrm{g}}$ & $6.95 \pm 0.20^{\mathrm{a}}$ & $34.07 \pm 0.10^{\mathrm{b}}$ & $35.34 \pm 0.15^{\mathrm{h}}$ \\
\hline T2 & $9.24 \pm 0.15^{\mathrm{b}}$ & $15.68 \pm 0.15^{\mathrm{k}}$ & $0.00 \pm 0.00$ & $51.36 \pm 0.10^{\mathrm{l}}$ & $41.78 \pm 0.05^{\mathrm{d}}$ & $16.61 \pm 0.20^{\mathrm{b}}$ \\
\hline T3 & $7.37 \pm 0.15^{\mathrm{a}}$ & $10.59 \pm 0.15^{\mathrm{f}}$ & $56.19 \pm 0.15^{\mathrm{i}}$ & $10.85 \pm 0.10^{\mathrm{c}}$ & $49.15 \pm 0.10^{\mathrm{h}}$ & $0.00 \pm 0.00$ \\
\hline T4 & $16.36 \pm 0.15^{\mathrm{e}}$ & $1.67 \pm 0.10^{\mathrm{a}}$ & $5.09 \pm 0.10^{\mathrm{a}}$ & $22.80 \pm 0.15^{\mathrm{i}}$ & $0.00 \pm 0.00$ & $0.00 \pm 0.00$ \\
\hline
\end{tabular}

Mean values and standard errors with different alphabets along the column are significantly different from each other at $P \leq 0.05$.The unit for ALT mean value in each case isnM/mg.

Table3.9. ALT production levels in the Gill of C. gariepinus exposed to sub-lethal concentrations of $\mathrm{CdCl}_{2}$ and supplemented with vitamin $C$ for a period of 12 weeks

\begin{tabular}{|l|l|l|l|l|l|l|}
\hline & $\mathbf{1}^{\text {st }}$ & $\mathbf{2}^{\text {nd }}$ & $\mathbf{3}^{\text {rd }}$ & $\mathbf{4}^{\text {th }}$ & $\mathbf{5}^{\text {th }}$ & $\mathbf{6}^{\text {th }}$ \\
\hline $\mathbf{C R}$ & $26.61 \pm 0.20^{\mathrm{j}}$ & $10.68 \pm 0.20^{\mathrm{g}}$ & $7.80 \pm 0.10^{\mathrm{b}}$ & $19.32 \pm 0.10^{\mathrm{h}}$ & $77.37 \pm 0.05^{\mathrm{l}}$ & $24.49 \pm 0.05^{\mathrm{f}}$ \\
\hline $\mathbf{T}_{\mathbf{1}}$ & $26.36 \pm 0.05^{\mathrm{i}}$ & $2.29 \pm 0.15^{\mathrm{b}}$ & $49.15 \pm 0.10^{\mathrm{f}}$ & $51.87 \pm 0.20^{\mathrm{m}}$ & $37.71 \pm 0.05^{\mathrm{c}}$ & $19.32 \pm 0.10^{\mathrm{c}}$ \\
\hline $\mathbf{T}_{\mathbf{2}}$ & $18.56 \pm 0.15^{\mathrm{f}}$ & $12.04 \pm 0.10^{\mathrm{i}}$ & $9.32 \pm 0.10^{\mathrm{c}}$ & $19.32 \pm 0.10^{\mathrm{h}}$ & $42.12 \pm 0.15^{\mathrm{e}}$ & $33.56 \pm 0.20^{\mathrm{g}}$ \\
\hline $\mathbf{T}_{\mathbf{3}}$ & $24.32 \pm 0.05^{\mathrm{h}}$ & $36.44 \pm 0.10^{\mathrm{n}}$ & $16.78 \pm 0.10^{\mathrm{d}}$ & $12.97 \pm 0.15^{\mathrm{e}}$ & $65.17 \pm 0.15^{\mathrm{k}}$ & $0.00 \pm 0.00$ \\
\hline $\mathbf{T}_{\mathbf{4}}$ & $14.24 \pm 0.10^{\mathrm{d}}$ & $11.61 \pm 0.05^{\mathrm{h}}$ & $26.61 \pm 0.10^{\mathrm{e}}$ & $50.09 \pm 0.24^{\mathrm{k}}$ & $0.00 \pm 0.00$ & $0.00 \pm 0.00$ \\
\hline
\end{tabular}

Mean values and standard errors with different alphabets along the column are significantly different from each other at $P \leq 0.05$. The unit for ALT mean value in each case isnM/mg.

From the results of the samples exposed to sub-lethal concentrations of $\mathrm{CdCl}_{2}$, and supplemented with vitamin E, the ALT production levels in the liver of the fish indicated that T2 mean values in both $2^{\text {nd }}$ and $4^{\text {th }}$ weeks of exposure, respectively are significantly higher than other treatments. The T2 and T1 
mean values in the $6^{\text {th }}$ and $8^{\text {th }}$ weeks of exposure, respectively are significantly higher than other treatments. T1 mean values in both $10^{\text {th }}$ and $12^{\text {th }}$ weeks of exposure are significantly higher than other treatments. The highest mean value of ALT produced in the liver was $76.70 \pm 0.15 \mathrm{nM} / \mathrm{mg}$ obtained in $\mathrm{T} 1$ at the end of the $8^{\text {th }}$ week of exposure. (Table 3.10). In another development, kidney's T1 and T2 mean values in $2^{\text {nd }}$ and $4^{\text {th }}$ weeks of exposure, respectively are significantly higher than other treatments. Also, T2 and T1 mean values in the kidneys of the samples at the end of the 6th and $8^{\text {th }}$ weeks of exposure, respectively are significantly higher than other treatments. The highest ALT production value of $71.78 \pm 0.05 \mathrm{nM} / \mathrm{mgin}$ the kidney of the samples was obtained in $\mathrm{T} 2$ at the end of the $6^{\text {th }}$ week of exposure. (Table 3.11).Furthermore, the T3 and T2 mean values in the gills of the samples in the $2^{\text {nd }}$ and $4^{\text {th }}$ weeks of exposure, respectively are significantly higher than other treatments. T2 and T4 mean values in the $6^{\text {th }}$ and $8^{\text {th }}$ weeks of exposure, respectively are significantly higher than other treatments.T1 mean values in both $10^{\text {th }}$ and $12^{\text {th }}$ weeks of exposure, respectively are significantly higher than other treatments. The highest mean value of ALT produced in the gill of the fish was $73.48 \pm 0.05 \mathrm{nM} / \mathrm{mgobtained}$ in $\mathrm{T} 1$ at the end of the $12^{\text {th }}$ week of exposure. (Table 3.12).

Table3.10. ALT production levels in the Liver of C. gariepinus exposed to sub-lethal concentrations of CdCl and supplemented with vitamin $E$ for a period of 12 weeks

\begin{tabular}{|l|l|l|l|l|l|l|}
\hline & $\mathbf{1}^{\text {st }}$ & $\mathbf{2}^{\text {nd }}$ & $\mathbf{3}^{\text {rd }}$ & $\mathbf{4}^{\text {th }}$ & $\mathbf{5}^{\text {th }}$ & $\mathbf{6}^{\text {th }}$ \\
\hline CR & $48.48 \pm 0.20^{\mathrm{n}}$ & $8.73 \pm 0.15^{\mathrm{a}}$ & $66.70 \pm 0.05^{\mathrm{m}}$ & $65.17 \pm 0.05^{\mathrm{n}}$ & $48.90 \pm 0.15^{\mathrm{d}}$ & $23.14 \pm 0.15^{\mathrm{c}}$ \\
\hline T1 & $17.37 \pm 0.05^{\mathrm{e}}$ & $16.44 \pm 0.10^{\mathrm{g}}$ & $56.10 \pm 0.20^{\mathrm{j}}$ & $76.70 \pm 0.15^{\mathrm{o}}$ & $49.58 \pm 0.15^{\mathrm{e}}$ & $75.59 \pm 0.10^{\mathrm{h}}$ \\
\hline T2 & $39.07 \pm 0.15^{\mathrm{m}}$ & $21.10 \pm 0.05^{\mathrm{j}}$ & $57.88 \pm 0.05^{\mathrm{k}}$ & $12.63 \pm 0.05^{\mathrm{d}}$ & $31.10 \pm 0.15^{\mathrm{c}}$ & $16.61 \pm 0.20^{\mathrm{b}}$ \\
\hline T3 & $18.22 \pm 0.05^{\mathrm{f}}$ & $19.32 \pm 0.10^{\mathrm{i}}$ & $50.85 \pm 0.20^{\mathrm{g}}$ & $7.88 \pm 0.05^{\mathrm{a}}$ & $0.00 \pm 0.00$ & $0.00 \pm 0.00$ \\
\hline T4 & $21.10 \pm 0.05^{\mathrm{g}}$ & $17.20 \pm 0.15^{\mathrm{h}}$ & $53.82 \pm 0.05^{\mathrm{h}}$ & $34.32 \pm 0.05^{\mathrm{k}}$ & $0.00 \pm 0.00$ & $0.00 \pm 0.00$ \\
\hline
\end{tabular}

Mean values and standard errors with different alphabets along the column are significantly different from each other at $P \leq 0.05$. The unit for ALT mean value in each case isnM/mg.

Table3.11. ALT production levels in the Kidney of C. gariepinus exposed to sub-lethal concentrations of $\mathrm{CdCl}_{2}$ and supplemented with vitamin $E$ for a period of 12 weeks

\begin{tabular}{|l|l|l|l|l|l|l|}
\hline & $\mathbf{1}^{\text {st }}$ & $\mathbf{2}^{\text {nd }}$ & $\mathbf{3}^{\text {rd }}$ & $\mathbf{4}^{\text {th }}$ & $\mathbf{5}^{\text {th }}$ & $\mathbf{6}^{\text {th }}$ \\
\hline CR & $65.68 \pm 0.15^{\mathrm{o}}$ & $21.87 \pm 0.10^{\mathrm{k}}$ & $68.39 \pm 0.15^{\mathrm{n}}$ & $12.54 \pm 0.10^{\mathrm{c}}$ & $54.32 \pm 0.05^{\mathrm{f}}$ & $16.10 \pm 0.10^{\mathrm{a}}$ \\
\hline T1 & $31.36 \pm 0.10^{\mathrm{j}}$ & $43.39 \pm 0.10^{\mathrm{m}}$ & $61.44 \pm 0.15^{1}$ & $47.97 \pm 0.20^{\mathrm{m}}$ & $19.41 \pm 0.15^{\mathrm{a}}$ & $54.41 \pm 0.10^{\mathrm{f}}$ \\
\hline T2 & $2.19 \pm 0.10^{\mathrm{a}}$ & $47.29 \pm 0.10^{\mathrm{o}}$ & $71.78 \pm 0.05^{\mathrm{o}}$ & $45.85 \pm 0.05^{\mathrm{l}}$ & $0.00 \pm 0.00$ & $0.00 \pm 0.00$ \\
\hline T3 & $10.43 \pm 0.15^{\mathrm{b}}$ & $46.70 \pm 0.05^{\mathrm{n}}$ & $11.53 \pm 0.10^{\mathrm{c}}$ & $21.19 \pm 0.10^{\mathrm{h}}$ & $0.00 \pm 0.00$ & $0.00 \pm 0.00$ \\
\hline T4 & $31.27 \pm 0.05^{\mathrm{i}}$ & $15.34 \pm 0.05^{\mathrm{f}}$ & $19.07 \pm 0.05^{\mathrm{d}}$ & $18.14 \pm 0.10^{\mathrm{e}}$ & $0.00 \pm 0.00$ & $0.00 \pm 0.00$ \\
\hline
\end{tabular}

Mean values and standard errors with different alphabets along the column are significantly different from each other at $P \leq 0.05$. The unit for ALT mean value in each case isnM/mg.

Table3.12. ALT production levels in the Gill of C. gariepinus exposed to sub-lethal concentrations of $C d C l_{2}$ and supplemented with vitamin E for a period of 12 weeks

\begin{tabular}{|l|l|l|l|l|l|l|}
\hline & $\mathbf{1}^{\text {st }}$ & $\mathbf{2}^{\text {nd }}$ & $\mathbf{3}^{\text {rd }}$ & $\mathbf{4}^{\text {th }}$ & $\mathbf{5}^{\text {th }}$ & $\mathbf{6}^{\text {th }}$ \\
\hline $\mathbf{C R}$ & $26.61 \pm 0.20^{\mathrm{h}}$ & $10.68 \pm 0.20^{\mathrm{c}}$ & $7.80 \pm 0.10^{\mathrm{a}}$ & $19.32 \pm 0.10^{\mathrm{f}}$ & $77.37 \pm 0.05^{\mathrm{h}}$ & $24.49 \pm 0.05^{\mathrm{d}}$ \\
\hline $\mathbf{T}_{\mathbf{1}}$ & $15.00 \pm 0.15^{\mathrm{d}}$ & $11.27 \pm 0.05^{\mathrm{d}}$ & $40.85 \pm 0.10^{\mathrm{f}}$ & $19.41 \pm 0.15^{\mathrm{g}}$ & $63.48 \pm 0.05^{\mathrm{g}}$ & $73.48 \pm 0.05^{\mathrm{g}}$ \\
\hline $\mathbf{T}_{\mathbf{2}}$ & $33.98 \pm 0.05^{\mathrm{k}}$ & $41.02 \pm 0.20^{\mathrm{l}}$ & $54.07 \pm 0.10^{\mathrm{i}}$ & $11.61 \pm 0.05^{\mathrm{b}}$ & $28.22 \pm 0.15^{\mathrm{b}}$ & $40.17 \pm 0.10^{\mathrm{e}}$ \\
\hline $\mathbf{T}_{\mathbf{3}}$ & $35.93 \pm 0.20^{1}$ & $9.15 \pm 0.10^{\mathrm{b}}$ & $.24 \pm 0.15^{\mathrm{b}}$ & $24.66 \pm 0.05^{\mathrm{i}}$ & $0.00 \pm 0.00$ & $0.00 \pm 0.00$ \\
\hline $\mathbf{T}_{\mathbf{4}}$ & $11.02 \pm 0.10^{\mathrm{c}}$ & $14.92 \pm 0.20^{\mathrm{e}}$ & $36.19 \pm 0.15^{\mathrm{e}}$ & $27.63 \pm 0.10^{\mathrm{j}}$ & $0.00 \pm 0.00$ & $0.00 \pm 0.00$ \\
\hline
\end{tabular}

Mean values and standard errors with different alphabets along the column are significantly different from each other at $P \leq 0.05$. The unit for ALT mean value in each case isnM/mg.

\section{DISCUSSIONS}

\subsection{ALT Production Levels in C. gariepinusexposed to Sub-Lethal Concentrations of Cd Toxicant and the Respective Supplemented Treatments with Vitamins A, C and E}

Transaminases such as GOT (Glutamate oxalo transaminase) and GPT (Glutamate pyruvate transaminase) represent useful biomarkers for biomonitoring of chemical pollutants in aquatic organisms, in which altered levels of transaminases indicate compensatory mechanism against impaired metabolism (Ramesh et al., 2014; Sathyaet al., 2012).From the results of the samples 
exposed to sub-lethal concentrations of $\mathrm{CdCl}_{2}$, the ALT production levels in the liver of the fish showed that $\mathrm{T} 1$ and $\mathrm{T} 4$ mean values in the $2^{\text {nd }}$ and $4^{\text {th }}$ weeks of exposure, respectively are significantly higher than other treatments including the control. The elicitation started early in the lowest concentration and then in the highest concentration subsequently probably to combat the prevailing condition posed by the effects of the toxicant. In line with this, Youniset al. (2012) reported that the levels of gluconeogenic enzymes are low under normal conditions, and Zinc increased sera AST and ALT activities in $O$. niloticus at both short and long exposure periods. The control mean values in the $6^{\text {th }}$ and $8^{\text {th }}$ weeks of exposure, respectively are significantly higher than other treatments. The oxidative stress generated by the xenobiotic may have culminated in the utilization of the available concentration of the enzyme in the treatments, hence, making them lower than the control mean values in these stages of the exposure; since it is known that the activity of AST and ALT enzymes in blood (any organ) can be used as a stress indicator (Awad-Elkareemet al., 2014). T1mean values in the $10^{\text {th }}$ week of exposure are significantly higher than other treatments. At this stage, there may be less utilization especially in the lowest treatments in combating the effects of the toxicant. The highest mean value of ALT produced in the liver was $65.43 \pm 0.10 \mathrm{nM} / \mathrm{mg}$ obtained in T4 at the end of the $6^{\text {th }}$ week of exposure probably due to the usual need for up-regulation of the body's defence system.Findings from El-Said El-Boshyet al. (2014) indicate that blood level activities of ALT and AST was significantly increased when the fish were exposed to 2,5 and $10 \mathrm{mg} / \mathrm{L}$ treatments for a period of 3 weeks. Furthermore, T1 and T4 mean values in the kidneys of the samples at the end of the $2^{\text {nd }}$ and $4^{\text {th }}$ weeks of exposure, respectively are significantly higher than other treatments. The triggering of the production of the enzyme started early in the lowest treatment and subsequently, the need for up-regulation of the defence system in the highest concentration at the end of the $4^{\text {th }}$ week of exposure. The control mean values in the $6^{\text {th }}$ and $10^{\text {th }}$ weeks of exposure are significantly higher than other treatments probably when the available ALT has been put to use in other treatments. T4 mean values in the $8^{\text {th }}$ week of exposure are significantly higher than other treatments including the control; andT4 mean value in the $4^{\text {th }}$ week of exposure recorded the highest ALT production value of $71.87 \pm 0.20 \mathrm{nM} / \mathrm{mgin}$ the kidney of the samples probably depicting the importance of the enzyme in mitigating the effect of the toxicant in combating the effects of the toxicant at these different stages of the exposure.In addition to the forgoing, the T3 and T4 mean values in the gills of the samples in the $2^{\text {nd }}$ and $4^{\text {th }}$ weeks of exposure are significantly higher than other treatments probably ensuring survival at these stages given that the concentrations are high necessitating immune up-regulation. This may also apply to T2 mean values in the $6^{\text {th }}$ week of exposure which are significantly higher than other treatments, and the highest mean value of ALT produced in the gill of the fish was $62.97 \pm 0.05 \mathrm{nM} / \mathrm{mgobtained}$ in T2as well as at the end of the $6^{\text {th }}$ week of exposure. The control mean values in the $8^{\text {th }}$ and $10^{\text {th }}$ weeks of exposure, respectively are significantly higher than other treatments. Similar finding indicated that Glucose, AST, ALT, Creatinine and cortisol increased significantly with increasing $\mathrm{Zn}$ concentration and exposure time, peaking at day 56 (AbdelTawwabet al., 2013).

From the results of the samples exposed to sub-lethal concentrations of $\mathrm{CdCl}_{2}$, and supplemented with vitamin A, the ALT production levels in the liver of the fish indicated that T4 mean values in both $2^{\text {nd }}$ and $4^{\text {th }}$ weeks of exposure, respectively are significantly higher than other treatments. This is most likely because of the need for up-regulation of the immune system of the body in the highest concentration especially at the early stages of the exposure when the fish are probably not yet adapted to the effects of the toxicant. Lower concentrations are probably un-perturbed at these stages due to the presence of the vitamin. This is probably why the T3 and T2 mean values in the $6^{\text {th }}$ and $8^{\text {th }}$ weeks of exposure, respectively are significantly higher than other treatments since the duration of exposure has increased and the production levels of the enzyme may have to be upgraded to counter the effects of the toxicant. This may also be the reason why the highest mean value of ALT produced in the liver $\left(73.48 \pm 0.15 \mathrm{nM} / \mathrm{mg}\right.$ )was also obtained in T3 at the end of the $6^{\text {th }}$ week of exposure. Furthermore, T2 and $\mathrm{T} 1$ mean values in the kidneys of the samples at the end of the $2^{\text {nd }}$ and $4^{\text {th }}$ weeks of exposure, respectively are significantly higher than other treatments. This is probably due to high production level of the enzyme and less utilization of same in combating the effects of the toxicant. This is also probably why T1 mean value in both $6^{\text {th }}$ and $8^{\text {th }}$ weeks of exposure,respectively are significantly higher than other treatments and the highest ALT production value of $81.61 \pm 0.15 \mathrm{nM} / \mathrm{mg}$ in the kidney of the samples at the end of the $4^{\text {th }}$ week of exposure was also obtained in T1. This high production 
value may also be as a result of the sensitivity of the kidneyin the presence of the vitamin in the lowest concentration of the exposure. In addition to the forgoing, the T2 and T4 mean values in the gills of the samples in the $2^{\text {nd }}$ and $4^{\text {th }}$ weeks of exposure, respectively are significantly higher than other treatments probably because of the need for up-regulation and sustenance of the enzyme production level to counter the effects of the toxicant. In like manner, T3 and T4 mean values in the $6^{\text {th }}$ and $8^{\text {th }}$ weeks of exposure, respectively are significantly higher than other treatments, and the highest mean value of ALT produced in the gill of the fish was $66.61 \pm 0.10 \mathrm{nM} / \mathrm{mgobtained}$ in T4as well at the end of the $4^{\text {th }}$ week of exposure. This may also be due to improved production level of the enzyme to combat the effects of the toxicant especially as the duration of the exposure increased.Literatures addressing the ameliorative roles of vitamin $\mathrm{A}$ in ameliorating the toxic effects of heavy metals in cat fishes are rare. However, Bashandy and Alhazza (2008) reported how $\mathrm{CdCl}_{2}$ significantly elevated blood hydroperoxide, AST, ALT, ALP, cholesterol and hepatic cadmium level and that the beneficial roles of $\beta$-carotene resulted in reducing the harmful effects of the toxicant.

From the results of the samples exposed to sub-lethal concentrations of $\mathrm{CdCl}_{2}$, and supplemented with vitamin C, the ALT production levels in the liver of the fish indicated that T3 and T4 mean values in the $2^{\text {nd }}$ and $4^{\text {th }}$ weeks of exposure, respectively are significantly higher than other treatments. The significance in the highest concentrations probably depicts the need for improvement in the body's defence mechanisms to counter the effects of the toxicant especially at the early stages of the exposure. This is probably why the increase in the enzyme production was sustained in T3 mean values in both $6^{\text {th }}$ and $8^{\text {th }}$ weeks of exposure, respectivelywhich are significantly higher than other treatments as the duration of the exposure progresses. This is also probably why the highest mean value of ALT produced in the liver was $60.43 \pm 0.15 \mathrm{nM} / \mathrm{mg}$ obtained in T3 at the end of the $6^{\text {th }}$ week of exposure. Similar finding by Effiong and Onyeze (2017) indicated that the highest effects were observed at $12.8 \mathrm{mg} / \mathrm{L}$ (highest concentration of the exposure) having total protein of $8.51 \mathrm{mmol} / \mathrm{L}$, AST $(14.39 \mathrm{mmol} / \mathrm{L})$, ALT $(16.99 \mathrm{mmol} / \mathrm{L})$, ALP $(66.0 \mathrm{mmol} / \mathrm{L})$, Uric acid $(0.68 \mathrm{mg} / \mathrm{L})$ and creatinine $(20.7 \mathrm{mg} / \mathrm{L}) . \mathrm{T} 1$ mean values in both $10^{\text {th }}$ and $12^{\text {th }}$ weeks of exposure are significantly higher than other treatments probably due to the need for up-regulation of the body's defence system in the presence of the vitamin as the duration increases culminating in less utilization. In another development, kidney's T1 mean values in both $2^{\text {nd }}$ and $4^{\text {th }}$ weeks of exposure, respectively are significantly higher than other treatments probably due to the need for early elicitation and less utilization in the presence of the vitamin. Also, T3 and T2 mean values in the kidneys of the samples at the end of both 6th and $8^{\text {th }}$ weeks of exposure, respectively are significantly higher than other treatments probably because as the duration and concentration of exposure increases the need for upregulation became even more important in combating the effects of the toxicant where the succoring effects of the vitamin can no longer be solely relied upon. This may also be the reason whythe highest ALT production value of $56.19 \pm 0.15 \mathrm{nM} /$ mgin the kidney of the samples was obtained in T3 at the end of the $6^{\text {th }}$ week of exposure. The T3 and T1 mean values in the $10^{\text {th }}$ and $12^{\text {th }}$ weeks of exposure, respectively are significantly higher than other treatments probably also in the light of increased production and less utilization as the duration of exposure increased. In addition to the forgoing, the $\mathrm{T} 1$ and T3 mean values in the gills of the samples in the $2^{\text {nd }}$ and $4^{\text {th }}$ weeks of exposure, respectively are significantly higher than other treatments. Early elicitation of the production of the enzyme in the lowest concentration and in the higher concentration subsequently, to combat the effects in the presence of the vitamin which probably ensures less utilization, hence its availability. This is also likely why T1 mean values in both $6^{\text {th }}$ and $8^{\text {th }}$ weeks of exposure, respectively are significantly higher than other treatments. Likewise, T3 and T2 mean values are significantly high than other treatments in the $10^{\text {th }}$ and $12^{\text {th }}$ weeks of exposure; and the highest mean value of ALT produced in the gill of the fish was $65.17 \pm 0.15 \mathrm{nM} / \mathrm{mgobtaine}$ in T3as well at the end of the $10^{\text {th }}$ week of exposure probably necessitated by the need for improved production and sustenance of the enzyme to counter the effects of the toxicant especially at later stages of the exposure.Similar report by Mozhdeganlooet al. (2016) indicated that permethrin significantly increased ALT, AST an DH activities in the liver perfusion medium and MDA level in liver tissue; the values of GSH and total antioxidant capacity (FRAP) in the liver tissue were significantly decreased due to permethrin administration, but PTN-0.64+ vitamin $\mathrm{C}$ group increased the values of GSH and FRAP, and decreased the level of MDA and the activities of hepatic enzymes when compared to the PTN-0.64 only group. 
From the results of the samples exposed to sub-lethal concentrations of $\mathrm{CdCl}_{2}$, and supplemented with vitamin E, the ALT production levels in the liver of the fish indicated that T2 mean values in both $2^{\text {nd }}$ and $4^{\text {th }}$ weeks of exposure, respectively are significantly higher than other treatments. This is probably indicative of the elicitation point or threshold in the production of the enzyme which are then sustained to combat the deleterious effects of the toxicant in the presence of the vitamin. As the duration of the exposure increases there were probably continuous productions and less utilization especially in the lower concentrations. This may be the reason why the T2 and T1 mean values in the $6^{\text {th }}$ and $8^{\text {th }}$ weeks of exposure, respectively are significantly higher than other treatments. This may also account for why $\mathrm{T} 1$ mean values in both $10^{\text {th }}$ and $12^{\text {th }}$ weeks of exposure are significantly higher than other treatments; and the highest mean value of ALT produced in the liver was $76.70 \pm 0.15 \mathrm{nM} / \mathrm{mg}$ obtained in $\mathrm{T} 1$ as well at the end of the $8^{\text {th }}$ week of exposure.In line with this, just as stated earlier,Fenget al. (2018) demonstrated how Cd administration resulted in damage of liver function and morphology in liver, which was expressed as the increased content of AST and ALT, rupture of organelles and decrease of CAT, SOD and GSH-Px activity; however, vitamin E and MT treatments protected against Cd-induced damage of liver in grass carp by decreasing AST, ALT content, repairing organelles and maintained the antioxidant system by elevating CAT, SOD and GSH-Px activity and regulating related mRNA transcript expression. In another development, kidney's T1 and $\mathrm{T} 2$ mean values in $2^{\text {nd }}$ and $4^{\text {th }}$ weeks of exposure, respectively are significantly higher than other treatments. This may also be as a result of the high production of the enzyme and less utilization in lower concentrations in the presence of the succoring effects of the vitamin at early stages of the exposure and even as the duration progresses. This is probably why T2 and T1 mean values in the kidneys of the samples at the end of the 6th and $8^{\text {th }}$ weeks of exposure, respectively are significantly higher than other treatments; and the highest ALT production value of $71.78 \pm 0.05 \mathrm{nM} / \mathrm{mg}$ in the kidney of the samples was obtained in $\mathrm{T} 2$ as well at the end of the $6^{\text {th }}$ week of exposure.Furthermore, the T3 and T2 mean values in the gills of the samples in the $2^{\text {nd }}$ and $4^{\text {th }}$ weeks of exposure, respectively are significantly higher than other treatments. The defence systems probably have to be improved upon early in these treatments to counter the effects of the toxicant. This need for improved ALT production probably continued in T2 and T4 mean values in the $6^{\text {th }}$ and $8^{\text {th }}$ weeks of exposure, respectively which are significantly higher than other treatments.T1 mean values in both $10^{\text {th }}$ and $12^{\text {th }}$ weeks of exposure, respectively are significantly higher than other treatments; and the highest mean value of ALT produced in the gill of the fish was $73.48 \pm 0.05 \mathrm{nM} / \mathrm{mgobtained}$ in T1 at the end of the $12^{\text {th }}$ week of exposure probably due to the fact that at this stage the concentration of the toxicant is low and the produced enzyme in the presence of the vitamin are less utilized in combating the effects of the toxicant. Moreover, at this stage there were high mortalities in higher concentrations where the effects of the enzyme as well as vitamin could no longer sustain the samples. Similar finding byTuncsoyet al. (2015) reported how exposure to $\mathrm{Cu}-\mathrm{CT}$ mixture decreased sera ALT activity on day 1 compared with $\mathrm{Cu}$ alone; exposure to $\mathrm{Pb}-\mathrm{CT}$ mixture decreased sera AST and ALT activities on day 15 compared with $\mathrm{Pb}$ alone due to the reactive amino groups of chitosan which forms complexes between metal ions and the polymer chain.

\section{CONCLUSIONS AND RECOMMENDATIONS}

The kidneys of the Cd only and CdVA groups had the highest ALT production values while the liver and gills in the CdVE and CdVC groups, respectively produced the highest ALT values. The high production values of ALT indicate physiological perturbations and as such, a good biomarker of oxidative stress elicited by the presence of the toxicant.

The highest ALT mean values produced in the various treatment groups include: Cd only $(71.87 \pm 0.20 \mathrm{nM} / \mathrm{mg}), \quad \mathrm{CdVA} \quad(81.61 \pm 0.15 \mathrm{nM} / \mathrm{mg}), \quad \mathrm{CdVC} \quad(65.17 \pm 0.15 \mathrm{nM} / \mathrm{mg})$ and CdVE $(76.70 \pm 0.15 \mathrm{nM} / \mathrm{mg})$ indicative of the various mechanisms adopted by the samples in dealing with the presence of the toxicant. These high production rates in CdVA kidneys and all the three organs in CdVE treatments in lower concentrations of the toxicant are indicative of, to some extent the ameliorative roles of the vitamins against the effects of the toxicant. 


\section{REFERENCES}

Abdel-Tawwab, M., Mousaad, N. M. M., Sharafeldin, K. M. (2013). Changes in growth and biochemical status of common carp, Cyprinuscarpio L. exposed to water-borne zinc toxicity for different periods. International Journal of Aquatic Research, 5(1), 11.

Abdel-Warith, A. A., Younis, E. M., Al-Asgah, N. A.,\&Wahbi, O. M. (2011). Effect of zinc toxicity on liver histology of Nile tilapia, Oreochromisniloticus. Scientific Research Essential, 6(17), 3760-3769.

Adewolu, M.A., Adeniji, C. A.,\&Adejobi, A. B. (2008). Feed utilization, growth and survival ofClariasgariepinus (Burchell, 1822) fingerlings cultured under different photoperiods. Aquaculture,283, 64-67.

Ahmed, N. F., Sadek, K. M., Soliman, M. K., Khalil, R. H., Khafaga, A. F., Ajarem, J. S., Maodaa, S. N., Allam, A. A. (2020). MoringaOleifera Leaf Extract Repairs the Oxidative Misbalance following SubChronic Exposure to Sodium Fluoride in Nile Tilapia Oreochromisniloticus. Animals,10, 626.

Arenas, J. J.,Villafranca, M., Nieto-Guindo, E., 'Alvaro S. M., Moreno, S. M.,Garrido, S.,\&Abil'es,J. (2017). Effectsof cyclic parenteral nutrition on parenteral-associated liverdysfunction parameters. Nutrition Journal, 16,1-8.

Athar, T., Waris, A. A. \&Nisar, M. (2018). A review on toxicity and environmental implications of heavy metals. Emergent Life Sciences Research, 4(2),31-37. Doi: https://doi.org/10.31783/elsr.2018.

AwadElkareem, M.M. A.,Karrar, A.M.H., \& Ali, A.K. S. (2014). Relationship of biometric size-weight, nutritive value, and metal concentrations in (Clariaslazera) (Cuvier and Valenciennes) reared in treated waste water. Jordan Journal of Biological Sciences, 7(3), 217-225.

Ayyat, M. S., Ayyat, A. M., Naiel, M. A., Al-Sagheer, A. A. ( 2020). Reversal effects of some safe dietary supplements on lead contaminated diet induced impaired growth and associated parameters in Nile tilapia. Aquaculture, 515, 734580 .

Bashandy, S. A., \&Alhazza, I. M. (2008). The hepatoprotective effects of $\beta$-Carotene against cadmium toxicity in rats. Journal of Pharmacology and Toxicology, 3, 457-463.

Das, P. C., Ayyappan, S., Das, B. K., \& Jena, J. K. (2004). Nitrite toxicity in Indian major carps: sublethal effect on selected enzymes in fingerlings of Catlacatla, Labeorohita, and Cirrhinusmrigala. Comparative Biochemistry and Physiology, 138, 3 - 10.

Effiong, M. U., \&Onyeze, M. E. (2017). Effects of ethanoic extracts of Ackee Apple (Blighiasapida) on biochemical parameters of Clariasgariepinus juveniles. Journal of Aquatic Sciences, 32(2), 317-322. Doi: https://dx.doi.org/10.4314.jas.v32i2.10.

El-Said El-Boshy, M., Gadalla, H. A., \&AbdEl-Hamied, F. M. (2014). Immunological, haematological and biochemical changes induced by short term exposure to cadmium in catfish (Clariasgariepinus). Journal of Coastal Life medicine, 2(3), 175-180. Doi:10.12980/JCLM.2.2014J57.

El-Shenawy, N. S.,\& Al-Ghamdi, O. A.(2014).Phenthoate inducedoxidativestress in fresh isolated mice hepatocytes. Alleviation by ascorbic acid.Toxicology, Environment and Health Science, 6 (2), 67-80.

FAO (2003). Food Security: concepts and measurement.Rome: Food and Agriculture Organization of the United Nations.In FAO (Ed.), Trade Reforms and Food Security. pp. 25-34.

FAO (2010). Food and Agricultural Organization of the United Nations: World Review of Fisheries and Aquaculture, http: // www. fao. org / docrep / 013/i1820e / i1820e01.pdf. Accessed 22/04/2019.

FAO (2012). The state of the world fisheries and aquaculture. Fisheries and Aquaculture Department, Rome, 2012.

Feng, Y., Huang, X., Duan, Y., Fan, W., Duan, J., Wang, K., .....,\& Yang, S. (2018).The Effects of Vitamin E and Metallothionein on the Antioxidant Capacities of Cadmium-Damaged Liver in Grass Carp, Ctenopharyngodonidellus.BioMed Research International,1-8. https://doi.org/10.1155/2018/ 7935396.

Karami, A., Christianus, A., Ishak, Z., Courtenay, S.C., Sayed, M.A., Noor, A. M.,\& Noor, S.H. (2010).Effect of triploidization on juvenile African catfish (Clariasgariepinus).AquacultureInternational, 18, 851-858.

Mehana, E. E., Khafaga, A. F., Elblehi, S. S., AbdEl-Hack, M. E., Naiel, M. A. E., Bin-Jumah, M., SarahI.Othman, S. I., \&Allam, A.A . (2020). Biomonitoring of Heavy Metal Pollution Using Acanthocephalans Parasite in Ecosystem: An Updated Overview.Animals,10, 811, 1-15. doi:10.3390/ ani10050811.

Merciai, R., Guasch, H., Kumar, A.,\&Sabater, S. (2014). Trace metal concentration and fish size: variation among fish species in a Mediterranean river. Ecotoxicology and Environmental Safety, 107, 154-163.

Monteiro, D.A., Rantin, F. T.,\&Kalinin, A. L. (2010). Inorganic mercury exposure: toxicologicaleffects, oxidative stress biomarkers and bioaccumulation in the tropical freshwater fish matrinxă, Bryconamazonicus (Spix and Agassiz, 1829). Ecotoxicology, 19, 105-123. 
Mozhdeganloo, Z. Jafari, A. M., Koohi, M. K., \&Heidarpour, M. (2016).Permethrin-induced oxidative damage in liver of rainbow trout (Oncorhynchusmykiss) and its attenuation by vitamin C. Iranian Journa of Veterinary Research, 17(1), 31-35.

Organization for Economic Cooperation and Development (2007).Maximum Acceptable Contaminants: guidance safety level. Fresh water fish (RPWS 1991). Pp. 12-28.

Pratt, T. C., Cullen, F. T., Sellers, C. S., Thomas, W. L., Madensen, T. D., Daigle, L. E., Fearn, N. E., \&Gau, J. (2010). The empirical status of social learning theory: a meta-analysis. Justice Quarterly, 27:6, 765-802. Doi: 10.1080/07418820903379610.

Ramesh, M., Sankaran, M., Veera-Gowtham, V., \&Poopal, R. K. (2014).Haematological, biochemical and enzymological responses in an Indian major carp, Labeorohita induced by sub-lethal concentration of water borne selenite exposure.Chemica and Biological Interraction, 207, 67-73.

Reitman, S.,\& Frankel, S. (1957). Glutamic-Pyruvate transaminase assay by colorimetric method. American Journal of Clinical Pathology, 28- 56.

Saglam, D., Atli, G., Dogan, Z., Baysoy, E., Gurler, C., Eroglu, A.,\&Canli, M. (2014).

Response of the antioxidant system of freshwater fish (Oreochromisniloticus) exposed to metals $(\mathrm{Cd}, \mathrm{Cu})$ in different hardness. Turkish Journal of Aquatic Science, 14, 43-52.

Sathya, V., Ramesh, M., Poopal, R.K., \&dinesh, B. (2012). Acute and sub-lethal effects in an

Indian major carp, Cirrhinusmrigata exposed to silver nitrate: Gill $\mathrm{Na}^{+} / \mathrm{K}^{+}$ATPase, plasma electrolytes and biochemical alterations. Fish and Shellfish Immunology, 32(5), 862-868.

Shilpi,G., Shilpi,S.,\&Sunita,S. (2015).Tolerance Against Heavy Metal Toxicity In Cyanobacteria: Role Of Antioxidant Defense System. International Journal of Pharmacy and Pharmaceutical Sciences, (7) (2), 0975-1491.

Thakur, V., \&Kanshere, R. R. (2014).Comparative Study on the Protective Role of Vitamin C and VitaminE on Mercury Induced Toxicity in Heteropneustsfossilis.International Research Journal of Science \& Engineering, 2 (2), 37-43.

Tingman, W., Jian, Z., \&Xiaoshuan, Z. (2010). Fish product qualityevaluation based on temperature monitoring in coldchain. African Journal of Biotechnology, 9, 6146-6151.

Tunçsoy, M., Duran, S., Ay, O., Cicik, B., \&Erdem, C. (2015). Effects of Copper And Lead Applied Singly and In Mixture with Chitosan on Some Sera Parameters ofClariasgariepinus.PSP 24, 9.Fresenius Environmental Bulletin, 3029-3034.

Yolanda, M.,\& Maria, L. I. (2012). Use of antioxidants for the treatment of cognitive and behavioural disorders in individuals with fragile X syndrome. WO2012080554.

Younis, E.M., Abdel-Warith, A.A., \& Al-Asgah, N.A. (2012). Hematological and Enzymatic Responses of Nile Tilapia, Oreochromisniloticus during Short and Long Term Sublethal Exposure to Zinc.African Journal of Biotechnology, 11(19), 4442-4446.

Zikic, R. V., Stajn, S., Pavlovic, Z., Ognjanovic, B. I., \&Saicic, Z. S. (2001). Activities ofsuperoxide dismutase and catalase in erythrocyte and plasma transaminases ofgoldfish (Carassiusauratusgibelio Bloch.) exposed to cadmium. Physiological Research, 50,105-111.

Citation: Samuel, Patrick Ozovehe et al." Assessment of the Ameliorative Roles of Vitamins A, C and Eon Alanine Aminotransferase (ALT) Productionin Clariasgariepinus (Burchell, 1822) Fingerlings Exposed To Cadmium Chloride", International Journal of Innovative Studies in Aquatic Biology and Fisheries (IJISABF), vol. 7, no.1, pp. 14-25, 2021. http://dx.doi.org/10.20431/2454-7670.0701003

Copyright: () 2021 Authors. This is an open-access article distributed under the terms of the Creative Commons Attribution License, which permits unrestricted use, distribution, and reproduction in any medium, provided the original author and source are credited. 